\title{
BUDIDAYA AYAM BROILER MELALUI RANCANG BANGUN ALAT KONTROL SUHU DAN KELEMBABAN KANDANG DI DESA BUMIHARJO KELING KABUPATEN JEPARA
}

\author{
Muhammad Sagaf $^{*}$, Budi Lofian ${ }^{2}$ \\ ${ }^{1}$ Program Studi Teknik Elektro Fakultas Sains dan Teknologi UNISNU Jepara \\ Jl. Taman Siswa (Pekeng) Tahunan Jepara \\ ${ }^{2}$ Program Studi Teknik Industri Fakultas Sains dan Teknologi UNISNU Jepara \\ Jl. Taman Siswa (Pekeng) Tahunan Jepara \\ *Email: sagaf_mnwr@yahoo.com
}

\begin{abstract}
Abstrak
Kelompok usaha budidaya ayam broiler Bumiharjo Broiler (mitra) di desa Bumiharjo kecamatan Keling kabupaten Jepara merupakan salah satu diantara beberapa kelompok usaha budidaya ayam broiler di kabupaten Jepara. Mitra mempunyai kendala usaha pada masa panen yang lama yaitu 35 hari, bobot ayam waktu panen 1,9 kg/ekor dengan Feed Convertion Ratio (FCR) 1,6. Pengaturan suhu dan kelembaban kandang untuk masa brooding (umur 1-2 minggu) menggunakan panas dari kayu bakar yang ditempatkan dalam drum bekas dan diberi lubang. Suhunya dikontrol secara manual oleh anak kandang yang harus secara rutin dan sering masuk kedalam kandang untuk melihat kondisi ayam dalam kandang. Sedangkan untuk masa setelah brooding, pengaturan suhu dan kelembaban hanya menggunakan tirai penutup kandang yang diatur besar kecil bukaannya serta penyiraman air di sekitar kandang secara manual oleh anak kandang. Sehingga suhu dan kelembaban yang diharapkan tidak bisa terjaga dengan konstan. Dan sangat tergantung pada tingkat kerajinan atau frekuensi pengecekan oleh anak kandang. Mitra juga mempunyai kendala pada manejemen usahanya. Solusi dan target luaran yang diberikan untuk mitra adalah mengadakan penyuluhan dan pendampingan tentang cara budidaya ayam broiler yang baik, penyuluhan dan pendampingan pembuatan alat kontrol suhu dan kelembaban kandang secara otomatis menggunakan pemanas gas elpiji pada masa brooding dan menggunakan blower dan mist sprayer pada masa setelah brooding, pendampingan perbaikan atap kandang yang rusak dan bocor, serta penggantian tirai penutup kandang, memberikan penyuluhan dan pendampingan perbaikan sistem sanitasi dan drainase serta memberikan penyuluhan tentang kewirausahaan, manajemen SDM, menghitung untung rugi dan pembukuan. Peningkatan daya saing/hasil pada mitra antara lain FCR turun menjadi 1,4, masa panen lebih cepat menjadi 32 hari, bobot ayam meningkat menjadi 2 kg/ekor, jumlah kematian turun $100 \%$ dan frekuensi pengontrolan langsung ke kandang juga menurun sebesar $100 \%$.
\end{abstract}

Kata kunci : ayam broiler, brooding, FCR, kontrol, suhu dan kelembaban

\section{PENDAHULUAN}

Kabupaten Jepara meskipun sebagian wilayahnya terletak di pesisir pantai, namun sebagian juga terletak di kaki gunung. Kondisi iklim yang seperti ini cocok untuk pembudidayaan ayam broiler, karena industri unggas di daerah tropis dihadapkan dengan tingginya suhu lingkungan, sehingga laju pertumbuhan yang dihasilkan tidak sesuai dengan potensi genetik yang dimiliki ternak. Ternak unggas tergolong hewan homeothermic (berdarah panas) dengan ciri spesifik tidak memiliki kelenjar keringat serta hampir semua bagian tubuhnya tertutup bulu. Kondisi seperti ini mengakibatkan kesulitan untuk membuang panas tubuhnya kelingkungan. Akibatnya, ternak unggas yang dipelihara didaerah tropis rentan terhadap bahaya stres panas.

Kelompok usaha budidaya ayam broiler Bumiharjo Broiler merupakan salah satu diantara beberapa kelompok usaha budidaya ayam broiler di kabupaten Jepara. Kelompok usaha ini diketuai oleh bapak M Khoirul Anam dan berlokasi di desa Bumiharjo kecamatan Keling kabupaten Jepara. 
Kelompok usaha Bumiharjo Broiler ini mempunyai fasilitas 1 buah kandang untuk budidaya dengan kapasitas 2000 ekor ayam broiler. Dengan masa panen 35 hari berat badan ayam yang dihasilkan rata-rata $1,9 \mathrm{~kg} / \mathrm{ekor}$ dan Feed Convertion Ratio (FCR) atau perbandingan antara jumlah pakan yang digunakan dengan jumlah bobot ayam broiler yang dihasilkan1,6. Sistem budidaya sudah menggunakan sistem kemitraan, namun hasil panen masih belum dapat maksimal.
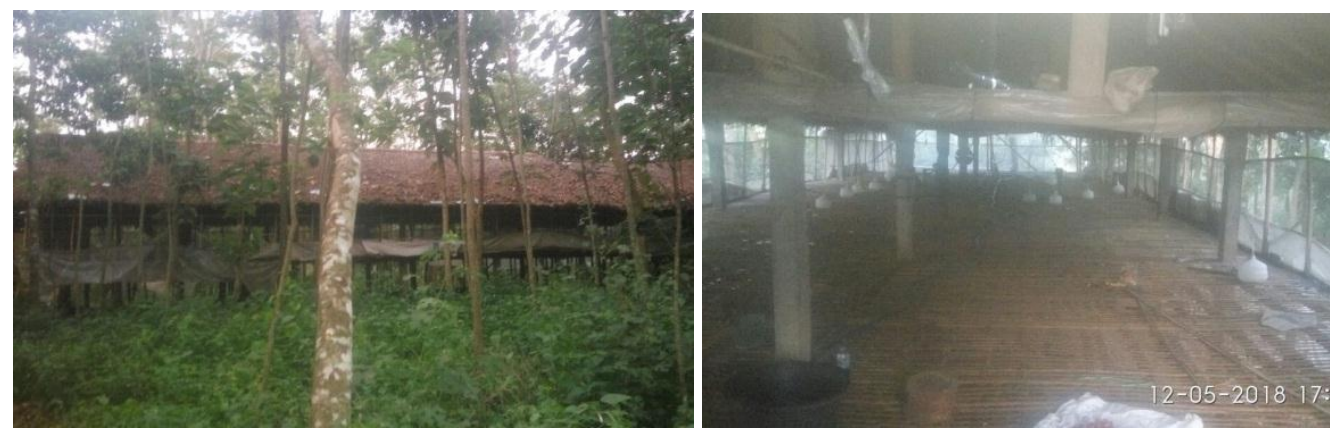

Gambar 1. Kondisi kandang ayam Bumiharjo Broiler

Pengaturan suhu dan kelembaban kandang untuk masa brooding (umur 1-2 minggu) menggunakan panas dari kayu bakar yang ditempatkan dalam drum bekas yang diberi lubang. Dan suhunya dikontrol secara manual oleh anak kandang yang harus secara rutin dan sering masuk kedalam kandang untuk melihat kondisi ayam dalam kandang. Sedangkan untuk masa setelah brooding, pengaturan suhu dan kelembaban hanya menggunakan tirai penutup kandang yang diatur besar kecil bukaannya serta penyiraman air di sekitar kandang secara manual oleh anak kandang. Sehingga suhu dan kelembaban yang diharapkan tidak bisa terjaga dengan konstan. Dan sangat tergantung pada tingkat kerajinan atau frekuensi pengecekan oleh anak kandang.
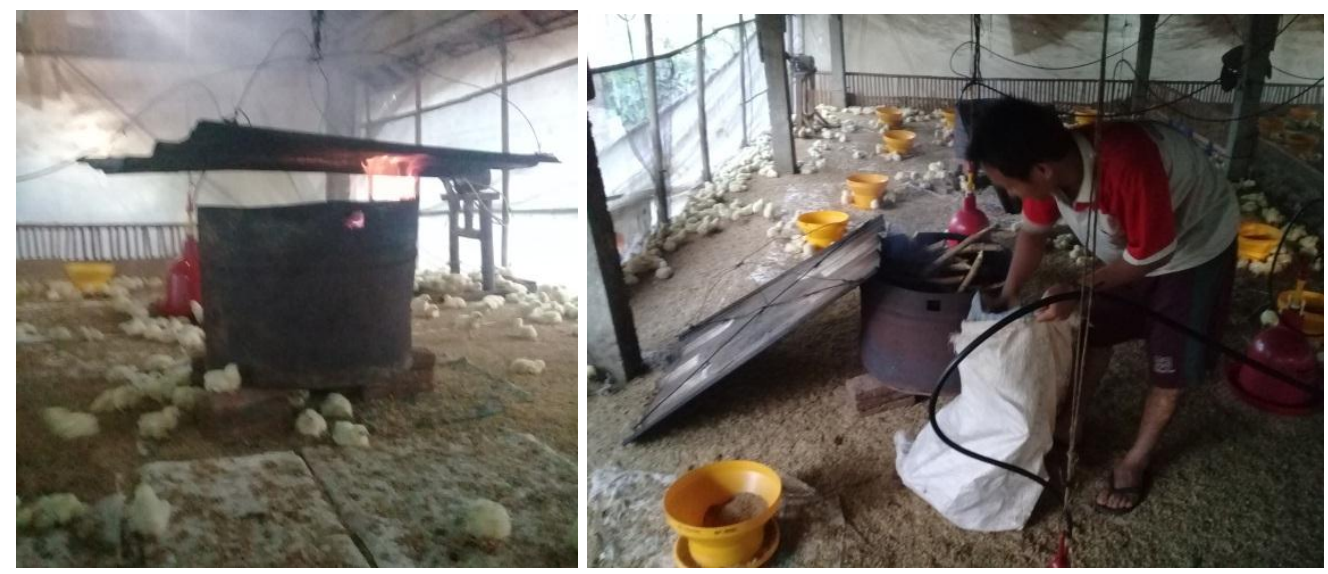

Gambar 2. Pengaturan suhu dan kelembaban kandang

Permasalahan yang dihadapi oleh mitra Bumiharjo Broiler di antaranya adalah:

1. Belum adanya pengetahuan yang memadai tentang cara budidaya ayam broiler yang baik.

2. Masa panen masih kurang cepat yaitu 35 hari.

3. Feed Convertion Ratio (FCR) yang masih cukup tinggi yaitu 1,6.

4. Pengaturan suhu kandang pada masa brooding masih manual menggunakan kayu bakar dan hanya mengandalkan anak kandang.

5. Pengaturan suhu kandang dan kelembaban pada masa setelah brooding masih manual dan hanya mengandalkan anak kandang untuk membuka tutup tirai dan penyiraman di sekitar kandang.

6. Kondisi atap kandang dan tirai penutup kandang banyak yang rusak dan berlubang.

7. Sistem drainase dan sanitasi masih kurang baik.

8. Belum adanya manajemen usaha, SDM dan pembukuan yang baik. 
METODE

Pelaksanaan kegiatan Program Kemitraan Masyarakat dalam rangka meningkatkan proses produksi dan hasil budidaya ayam broiler adalah sebagai berikut:

1. Metode transfer teknologi dan penerapan iptek.

Transfer teknologi pada kelompok mitra budidaya ayam broiler adalah sistem atau teknik budidaya dengan mengontrol suhu dan kelembaban kandang secara otomatis sesuai dengan umur ayam, sehingga dapat meningkatkan hasil produksi yang diharapkan mampu memenuhi kebutuhan pasar ayam broiler saat ini.

2. Sosialisasi dan pelatihan manajemen usaha

Pelaksanaan kegiatan ini dilakukan dengan memberikan sosialisasi pada satu desa secara keseluruhan, meskipun secara teknis kegiatan akan difokuskan pada kelompok sasaran yang menjadi prioritas utama, yaitu kelompok usaha budidaya ayam broiler Bumiharjo Broiler. Diharapkan anggota kelompok yang terlibat adalah anggota yang mampu menjadi pioneer untuk mentransferkan dan menjadi contoh bagi masyarakat sekitar khususnya pembudidaya ayam broiler.

3. Pendampingan

Pendampingan dilakukan dengan mendampingi mitra dalam pembuatan alat kontrol suhu dan temperatur kandang secara otomatis, perbaikan atap kandang dan tirai, perbaikan sistem sanitasi dan drainase, perbaikan manajemen dan pembukuan.
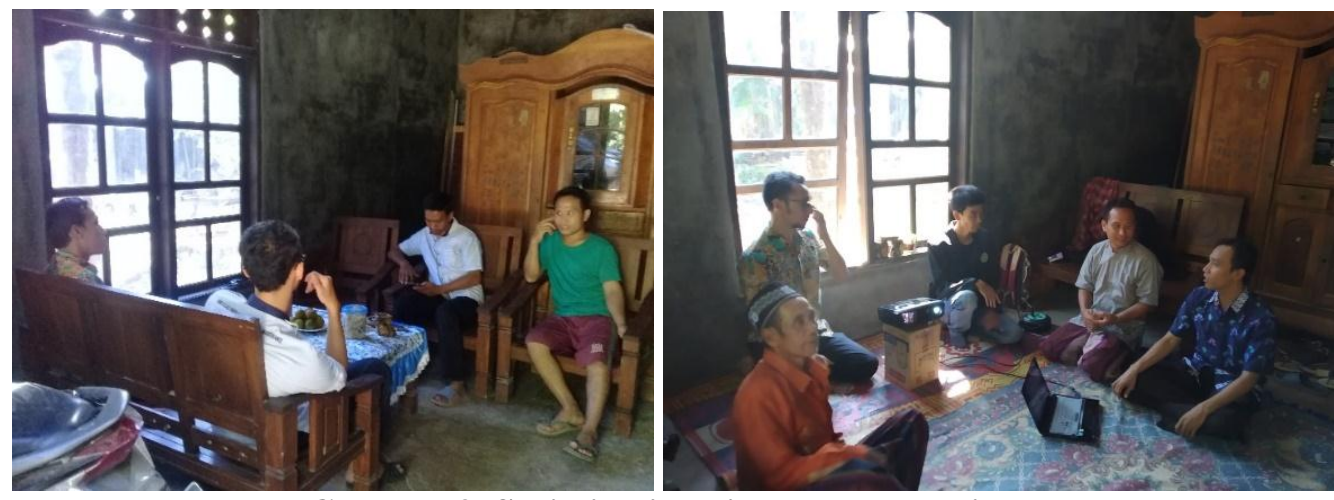

Gambar 3. Sosialisasi kegiatan dan pelatihan
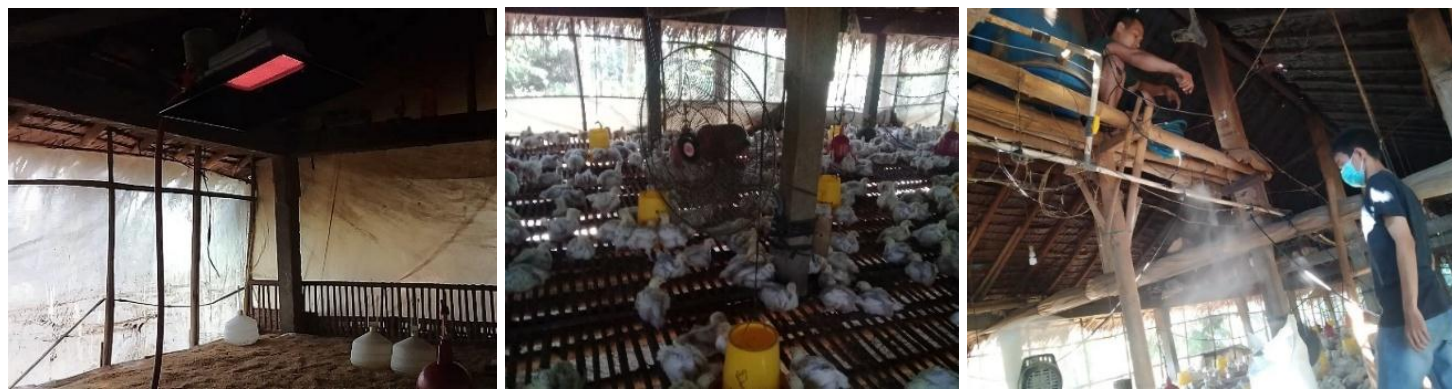

Gambar 4. Pendampingan pembuatan alat kontrol suhu dan kelembaban otomatis

Berdasarkan analisis situasi, permasalahan dan metode yang sudah dijelaskan sebelumnya, maka solusi untuk menyelesaikan permasalahan dapat diuraikan pada tabel 1 . 
Tabel 1. Permasalahan dan Solusi pada Mitra

\section{Permasalahan}

Belum adanya pengetahuan yang memadai tentang cara budidaya ayam broiler yang baik, masa panen kurang cepat 35 hari, FCR tinggi 1,6.

Pengaturan suhu pada masa brooding masih manual menggunakan kayu bakar dan hanya mengandalkan anak kandang.

Pengaturan suhu dan kelembaban kandang pada masa setelah brooding masih manual dan hanya mengandalkan anak kandang untuk membuka tutup tirai dan penyiraman disekitar kandang.

Kondisi atap kandang banyak yang rusak dan berlubang, kondisi tirai penutup kandang banyak yang rusak dan sobek.

Sistem drainase dan sanitasi masih kurang baik.

Belum adanya manajemen usaha, SDM dan pembukuan yang baik.
Penyuluhan dan pendampingan pembuatan alat kontrol suhu dan kelembaban kandang secara otomatis menggunakan pemanas gas elpiji pada masa brooding.

Penyuluhan dan pendampingan pembuatan alat kontrol suhu dan kelembaban kandang secara otomatis menggunakan blower dan mist sprayer pada masa setelah brooding.

Pendampingan perbaikan atap kandang yang rusak dan bocor, serta penggantian tirai penutup kandang.

Memberikan penyuluhan dan Pendampingan perbaikan sistem sanitasi dan drainase.

Memberikan penyuluhan tentang kewirausahaan, manajemen SDM, menghitung untung rugi dan pembukuan

\section{HASIL DAN PEMBAHASAN}

Kegiatan pengabdian ini dimulai dengan survey untuk melihat kondisi terakhir mitra untuk menyusun dan menyesuaikan program yang telah direncanakan sebelumnya. Kegiatan survey diikuti dengan sosialisasi kegiatan pengabdian di mitra yang dilaksanakan pada tanggal 29 April 2019. Kegiatan dilanjutkan dengan melakukan pengujian kapasitas pemanas di kandang ayam mitra pada tanggal 15 Mei 2019 dan simulasi alat kontrol pemanas di laboratorium Teknik Elektro Universitas Islam Nahdlatul Ulama (UNISNU) Jepara pada tanggal 22 Mei 2019. Pengujian kapasitas blower dan sprayer juga dilakukan di kandang ayam mitra pada tanggal 27 Juni 2019 dan diikuti simulasi alat kontrol suhu dan kelembaban di laboratorium Teknik Elektro UNISNU Jepara pada tanggal 8 Juli 2019. Pemasangan dan perakitan alat kontrol suhu dan kelembaban di kandang mitra dilakukan pada tanggal 17 Juli 2019. Pelatihan penggunaan alat kontrol suhu dan kelembaban kandang sekaligus penyerahan alat dilakukan pada tanggal 25 Juli 2019. Seluruh kegiatan dilakukan dengan melibatkan 2 orang mahasiswa Teknik Elektro untuk membantu pelaksanaan kegiatan sekaligus memberi kesempatan kepada mereka untuk langsung terjun ke masyarakat.
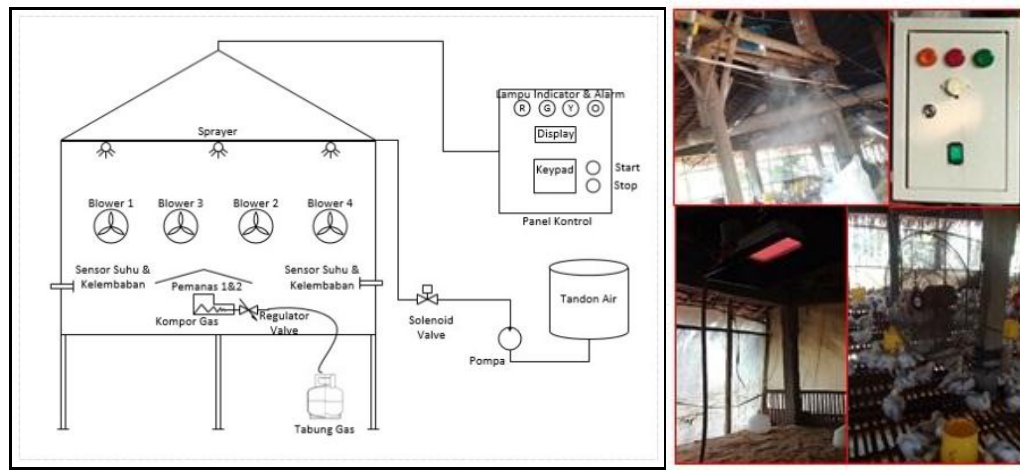

Gambar 5. Alat kontrol suhu dan kelembaban kandang ayam 
Hasil yang didapat dari program pengabdian pada mitra dapat dilihat pada tabel 2.

Tabel 2. Peningkatan hasil dan daya saing mitra

\begin{tabular}{lcccc}
\hline \multicolumn{1}{c}{ Uraian } & Sebelum Program & Setelah Program & Peningkatan \\
\hline Feed Convertion & Ratio & 1,6 & 1,4 & $14 \%$ \\
(FCR) & 35 & 32 & $9 \%$ \\
Masa Panen (hari) & 1,9 & 2 & $5 \%$ \\
Bobot Ayam (kg) & 200 & 100 & $100 \%$ \\
Jumlah Kematian (ekor) & 8 & 4 & $100 \%$ \\
$\begin{array}{l}\text { Frekuensi pengontrolan } \\
\text { kandang (kali/hari) }\end{array}$ & & & \\
\hline
\end{tabular}
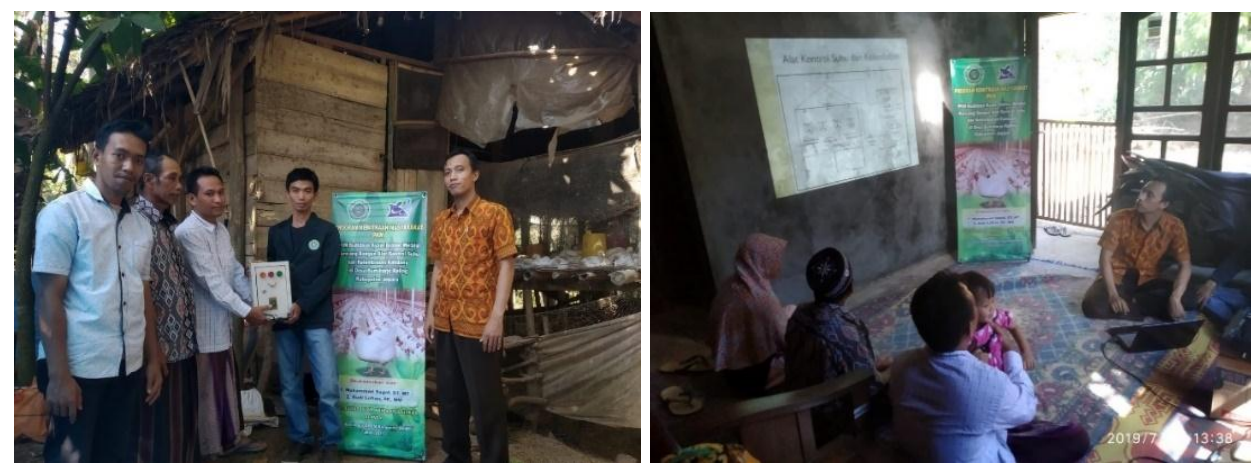

Gambar 6. Penyerahan alat kontrol suhu dan kelembaban otomatis (kiri) dan pelatihan penggunaan alat kontrol (kanan)

\section{KESIMPULAN}

Program pengabdian yang dilakukan pada mitra berhasil meningkatkan daya saing mitra. Hal ini terlihat dari FCR turun menjadi 1,4, masa panen lebih cepat menjadi 32 hari, bobot ayam meningkat menjadi $2 \mathrm{~kg} / \mathrm{ekor}$, jumlah kematian turun 100\% dan frekuensi pengontrolan langsung ke kandang juga menurun sebesaar 100\%. Selain dapat meningkatkan daya saing, program pengabdian ini juga membantu untuk meringankan/mengurangi beban kerja mitra karena alat produksi yang digunakan beroperasi secara otomatis. Sehingga mitra tidak harus terlalu sering untuk mengecek kondisi kandang ayam.

\section{UCAPAN TERIMAKASIH}

Terimakasih disampaikan kepada DRPM RISTEKDIKTI yang telah membiayai program pengabdian masyarakat ini.

\section{DAFTAR PUSTAKA}

Eko Wiji Setio Budianto, 2017, Prototipe Sistem Kendali Pengaturan Suhu Dan Kelembaban Kandang Ayam Boiler Berbasis Mikrokontroler Atmega 328, Prosiding Seminar Nasional Ilmu Komputer dan Teknologi Informasi, Vol. 2, No. 2, September 2017

Makmur, 2018, Perancangan Prototipe Kandang Ayam Broiler Closed House Untuk Kontrol Suhu

Dan Kelembaban Berbasis Arduino Mega 2560,Tugas Akhir Teknik Elektro UMS

Dr. Ir. Muhammad Rasyaf, 2012, Panduan Beternak Ayam Pedaging, Penerbit Penebar Swadaya

Ferry Tamaludin, 2012, Ayam Broiler 22 Hari Panen Lebih Untung, Penerbit Penebar Swadaya 